\title{
Geochemistry and Determination of Mineral Properties of Dolomite Deposit in Ikpeshi Southern, Nigeria
}

\author{
A. O. Omoseebi and I. Y. Tanko
}

\section{ABSTRACT}

\begin{abstract}
This work focused on the geochemistry and determination of the mineral properties' distribution of dolomite deposit from Ikpeshi, using variogram analysis, Samples collected from the study area were subjected to laboratory analysis to determine the porosity, water content and geochemical properties. Variograms maps were constructed and fitted to the model. The results of the variogram analysis were used in plotting of predictive maps which show the property distribution of the dolomite. The porosity varies between $0.68 \%-3.24 \%$ and the Water Content varies between $0.1-1.65 \%$. The geochemical analyses reveal that the average concentration of the elemental oxides is $1.790,0.461,0.299,0.045,20.380$ and 46.130 for $\mathrm{SiO}_{2}, \mathrm{Al}_{2} \mathrm{O}_{3}, \mathrm{Fe}_{2} \mathrm{O}_{3}, \mathrm{MnO}, \mathrm{MgO}$ and $\mathrm{CaO}$, respectively. $\mathrm{CaO}$ and $\mathrm{MgO}$ are more abundant when compared with other major elements; the predictive maps of the distribution and directions of the mineral properties and the distribution are not uniform in all directions which indicates that the mineral properties of the dolomite deposit are anisotropic.
\end{abstract}

Keywords: Dolomite, Geochemistry, Porosity, Variogram.
Published Online: October 04, 2021

ISSN: $2684-446 \mathrm{X}$

DOI : $10.24018 /$ ejgeo.2021.2.5.175

\section{A. O. Omoseebi*}

Department of Mining Engineering, Federal University of Technology Akure, Nigeria.

(e-mail: omoseebiao@gmail.com)

I. Y. Tanko

Department of Geology and Mining, Nasarawa State University Keffi, Nigeria. (e-mail: iyantanko2014@gmail.com)

"Corresponding Author

\section{INTRODUCTION}

\section{A. Background to the Study}

Dolomite is a common rock-forming mineral and is rarely found in modern sedimentary environments. It is a calcium magnesium carbonate with a chemical composition of $\mathrm{CaMg}\left(\mathrm{CO}_{3}\right)_{2}$ [1]. Dolomite were originally deposited as calcium carbonate muds that were post depositionally altered by magnesium-rich pore water to form dolomite [2].

Dolomite deposits were also found in some areas in Nigeria to be located in Abuja, Edo (Ikpeshi and Akoko), Kogi, Nasarawa, Kwara, Yobe, and Oyo State. Dolomite is one of the compositions of limestone that can also be referred to as the sedimentary rock. Limestone that contains some dolomite is known as dolomitic limestone [1]. Dolomite and limestone are very similar rocks. They share the same color ranges from white-to-gray and white-to-light brown. They are approximately of the same hardness, Dolomite has a Mohs hardness of 3.5 to 4 and limestone with Mohs hardness of 3 and they are both soluble in dilute hydrochloric acid. Dolomite and limestone behave alike when subjected to heat and pressure [3]. It begins to recrystallize as the temperature increases. As this occurs, the size of the dolomite crystals in the rock increases, and the rock develops a distinctly crystalline appearance.

Most Nigerians and West Africans may not be conversant with what dolomite actually is and the word may really sound new to some people when being compared to some of the minerals commonly found in the country. It is not found in many states in Nigeria. Its quarrying is the same with limestone and most of the companies in Nigeria that are into limestone processing are likely also to be into the quarrying of dolomite. It has many commercial and industrial uses, and because of this, there are many businessmen in Nigeria and numerous African countries that has invested in the mineral dolomite, there are also a number of exporters and suppliers of this natural mineral resources across Nigeria. Dolomite is form when the calcite $\left(\mathrm{CaCO}_{3}\right)$ in carbonate mud or limestone is modified by magnesium-rich groundwater. The available magnesium facilitates the conversion of calcite into dolomite $\left(\mathrm{CaMg}\left(\mathrm{CO}_{3}\right)_{2}\right)$. This chemical change is known as dolomitization [4]. Pure dolomite is composed of $45.7 \%$ $\mathrm{MgCO}_{3}$ and $54.3 \% \mathrm{CaCO}_{3}$ or $30.4 \%$ lime $(\mathrm{CaO})$ and $21.8 \%$ Magnesia $(\mathrm{MgO})$. A value of $\mathrm{MgO}$ greater than $1 \%$ in limestone suggests that the mineral dolomite is present [4]. The dolomitization is the process which results in a slight volume reduction when limestone is converted into dolomite [5]. This can produce a porosity zone in the strata where dolomitization has taken placed. These pore spaces can be traps for subsurface fluids like water, oil and natural gas. This is why dolomite is often a reservoir rock that is sought in the exploration for oil and natural gas. Dolomite can also serve as a host rock for lead, zinc, and copper deposits [5].

The term dolostone was introduced to avoid confusion with the mineral dolomite. The usage of the term dolostone is controversial because the name dolomite was first applied to the rock during the late 18 th century and thus has technical precedence. The use of the term dolostone is not recommended by the Glossary of Geology published by the American Geological Institute. It is, however, used in some geological publications. The geological process of 
conversion of calcite to dolomite is known as dolomitization and any intermediate product is known as "dolomitic limestone [5]. Ikpeshi in Edo State lies within latitudes $7^{\circ} 06^{\prime}$ $00^{\prime \prime} \mathrm{N}$ to $7^{\circ} 20^{\prime} 00^{\prime \prime} \mathrm{N}$ and longitudes $6^{\circ} 08^{\prime} 30^{\prime \prime} \mathrm{E}$ to $6^{\circ} 20^{\prime} 64^{\prime \prime} \mathrm{E}$ southern Nigeria. Ikpeshi area lies within the Precambrian Basement Complex of Southwest, Nigeria. The Basement rocks are notably the migmatite gneiss complex, schist (metasediment), older granite and late intrusive [6], [7]. Fig. 1 shows the location and geology of the study area. The metasedimentary rocks at Ikpeshi areas comprise mainly quartz-biotite schist, calc silicate and marble, mica schist and granulites.

Geostatistics is a branch of statistics focusing on spatial or datasets. It was originally developed to predict probability distributions of ore grades for mining operations [8]. Variogram describes the degree of discontinuity of a variable as a function of lag distance and direction [9]. Geostatistical methods for building geological models all make use of the variogram.

Semi-Variogram is an interpolation technique, which is built on the assumption that things that are close to one another are more alike than those farther away (quantified here as spatial autocorrelation). The empirical semivariogram is a means to explore this relationship. Pairs that are close in distance should have a smaller measurement difference than those farther away from one another.

\section{B. Characteristics of Semi-variogram}

The Range and Sill in semi-variogram modelling, the distance from where the first model flattens out is known as range. The value that the semi-variogram model attains at the range on y-axis is known as sill.

The nugget: Theoretically, if separation distance is zero (lag =0), semi-variogram value should be zero, however, at small separation distance, the difference between measurements and separation distance does not tends to zero, this is call nugget effect. The nugget effect can be attributed to measurement errors. Measurement of error occurs because of the error inherent in measuring devices. Natural phenomena can vary spatially over a range of scales. Variation at micro scales smaller than the sampling distances will appear as part of the nugget value. Before collecting data, it's important to gain some understanding of the scales of spatial variation.

\section{MATERIAL AND METHODS}

Sixty (60) samples of dolomite were collected from the study area by means of sledge hammer and chisel. Global positioning system (GPS) instrument was used to locate and determine the elevations and co-ordinates of sampled points. The mine pit (Quarry Face) was gridded and the grid interval was five meters $(5 \mathrm{~m})$ north - south and east - west apart and samples were collected. The geological map of the study area and the map of the sample location are shown in Fig. 1 and 2.

The porosity test was conducted on samples according to International Society for Rock Mechanics (ISRM) Suggested Methods "Rock Characterization, Testing and Monitoring" [11].

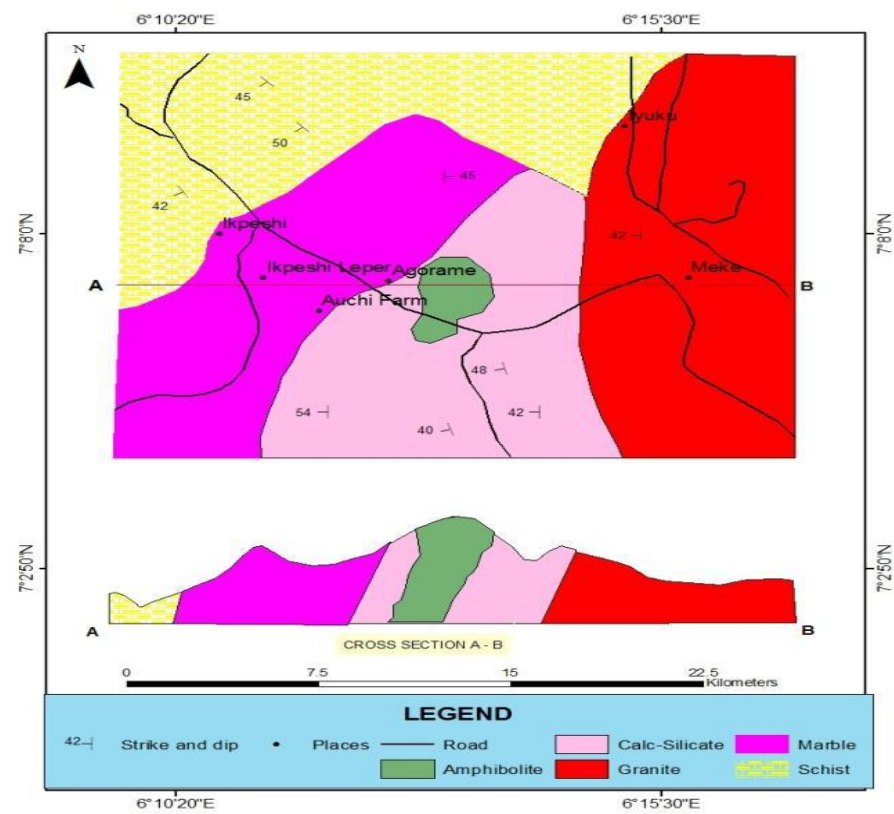

Fig. 1. Geological map of Ikpeshi area (modified after [10].

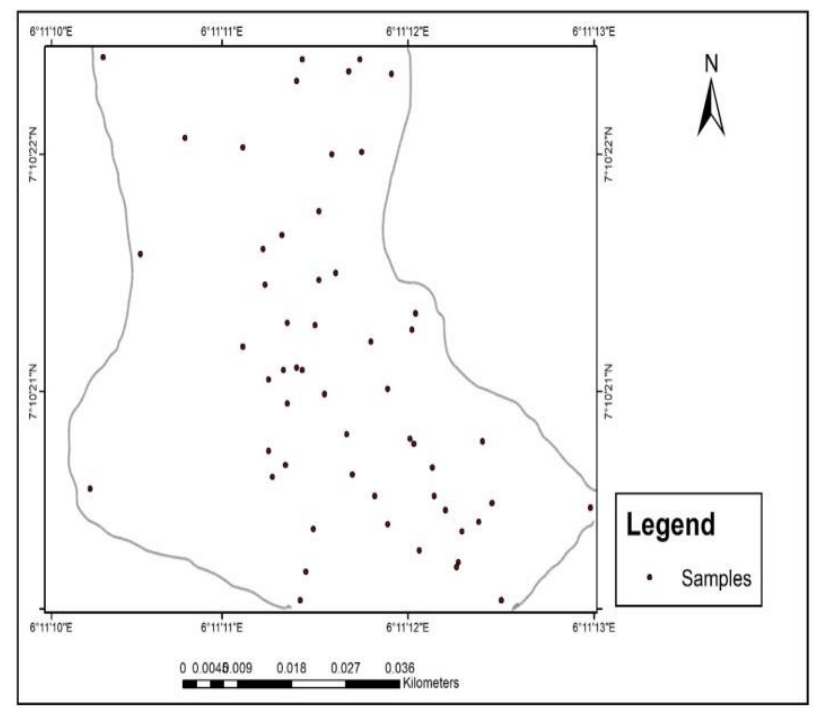

Fig. 2. Sample points and boundary of the study area.

Water Content was determined based on International Society for Rock Mechanics Suggested Methods "Rock Characterization, Testing and Monitoring" The test procedures were in line with the [11] methods.

The geochemical analysis was conducted using Atomic Absorption Spectrophotometer (AAS).

- One gram (1 g) from each of the samples collected was pulverized and grinded into powder (180 $\mu \mathrm{m}$ mesh).

- The weighed samples were digested using $10 \%$ hydrofluoric acid.

- The digested samples were filtered using whatman filter and made up with distilled water.

- It was kept for two (2) hours. Ready to be analyzed by Atomic Absorption Spectrophotometer (AAS) which gives the reading in part per million ( $\mathrm{ppm}$ ) this was converted to Oxides (wt $\%$ ).

\section{RESUlTS AND DISCUSSION}

This section analyzed the data obtained for both physical and chemical analysis of dolomite samples at Golden Girl Quarry Girl Quarry. 
A. Relationship between \%Water Content and \% Porosity Content of the Dolomite Samples

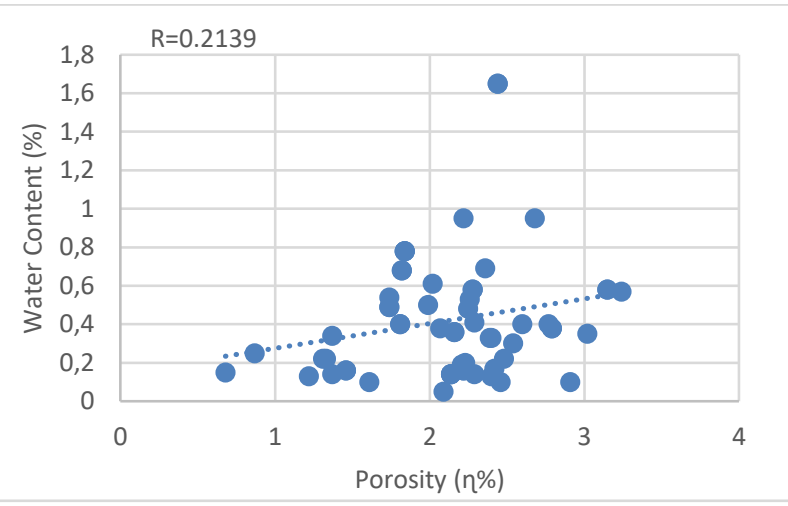

Fig. 3. Scatter matrix of the \%Water Content and \% Porosity content of the dolomite samples.

$$
\mathrm{wc}=0.1285 \eta+0.1466 \text {, }
$$

wc is water content, $\eta$ is porosity.

\section{B. Correlation Plot among the Oxides}

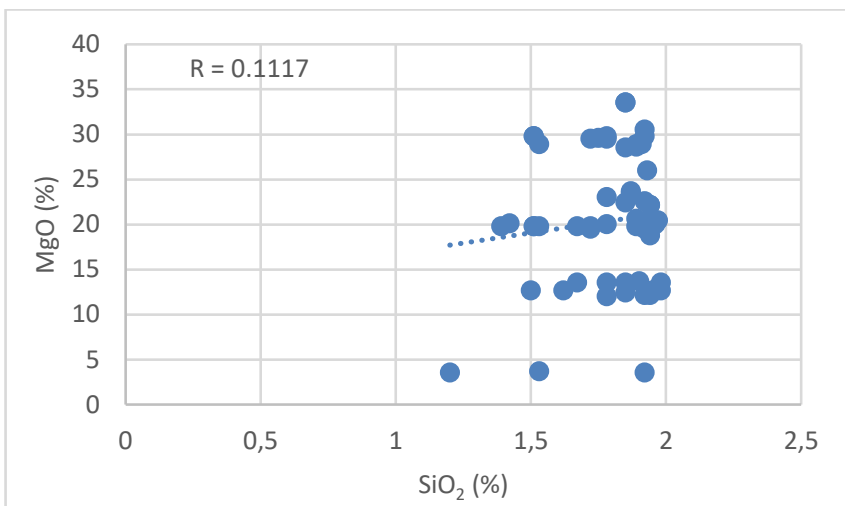

Fig. 4. Correlation Plot of $\mathrm{SiO}_{2}$ and $\mathrm{MgO}$ contents.

$$
w c=4.5296 \eta+12.271
$$

$w c$ is water content, $\eta$ is porosity

As revealed in Fig. 3, the correlation coefficient (R) between the $\%$ Water Content and \% Porosity is 0.2 . This value is very low; hence it shows lack of strong interrelationship between the two mineral properties.

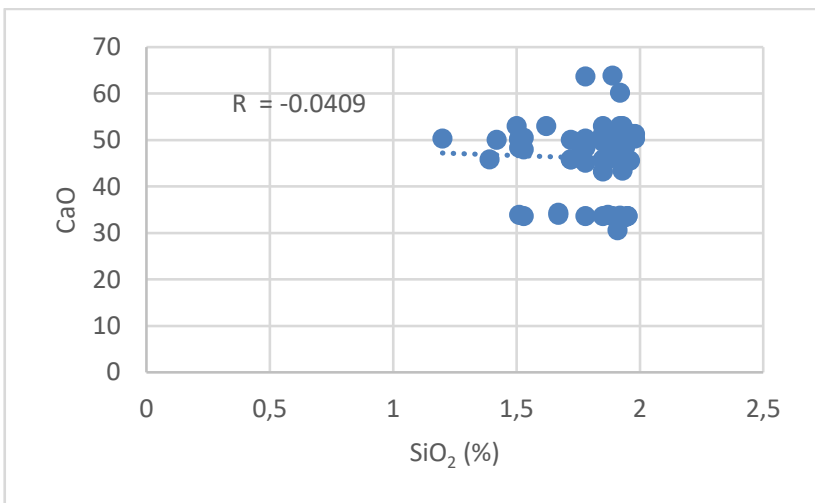

Fig. 5. Correlation Plot of $\mathrm{SiO}_{2}$ and $\mathrm{CaO}$ contents.

$$
w c=-1.8042 \eta+49.368
$$

The relationship between the major minerals ( $\mathrm{MgO}$ and $\mathrm{CaO}$ ) and the Silicate were further investigated through plotted correlation matrix (Fig. 4. and 5). The coefficient of correlation (R) values obtained when $\mathrm{SiO}_{2}$ was plotted against $\mathrm{MgO}$ and $\mathrm{CaO}$ are 0.1117 and -0.0409 , respectively. Thus, for a given sample location, the concentration of $\mathrm{MgO}$ and $\mathrm{CaO}$ shows an inverse relationship with the $\mathrm{SiO}_{2}$. This kind of inverse relationship is an indication of high purity level of the dolomite deposit under investigation

\section{Variogram Analysis and Predicted Maps of the Property Distribution of Dolomite in the Study Area}

In variogram Analysis, Geographical Information System (GIS) ArcGis software was used to analyze the data and to plot Semi-Variogram curve, predicted map for each of the property were also obtained. Prior to geostatistical analysis, statistical analyses of the concentration of different oxides were obtained.

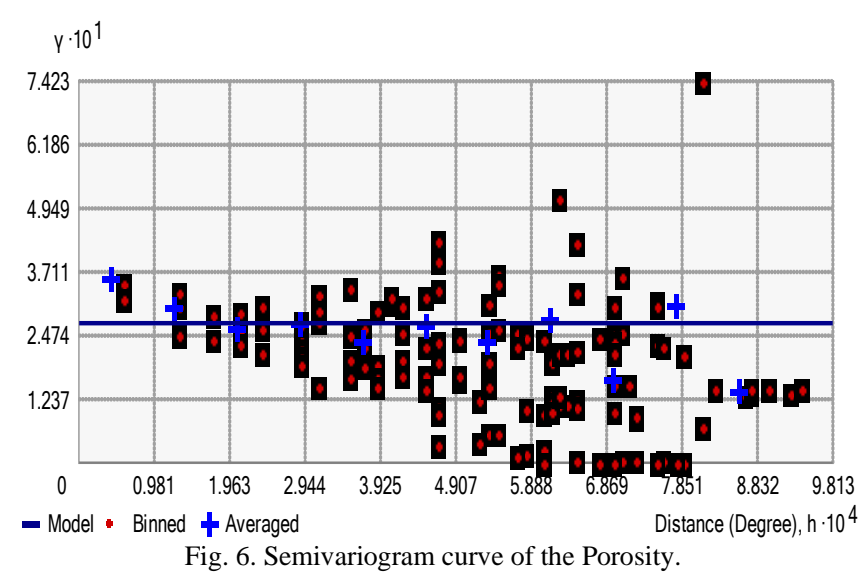

Nugget: 0.2715947

Major Range: 0.0009813146

Partial Sill: 0

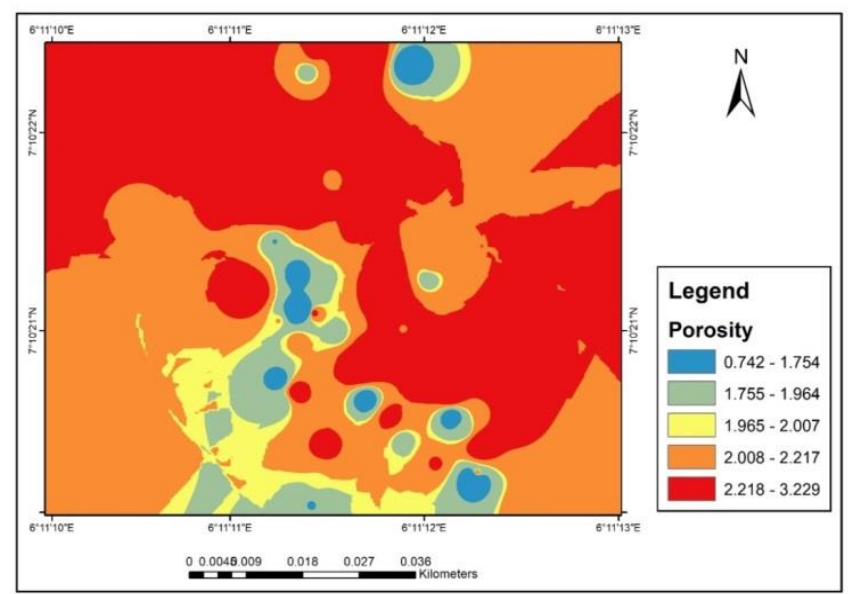

Fig. 7. Predicted Map Showing the Porosity Distribution in the study Area.

As revealed in (Fig. 6). The variogram structure for the porosity indicating the spatial correlation between adjoining samples has a range of $9.8 \mathrm{~m}$ while the nugget value is 2.7 . The porosity content increases from south to north in (Fig. 7).

$w c$ is water content, $\eta$ is porosity. 


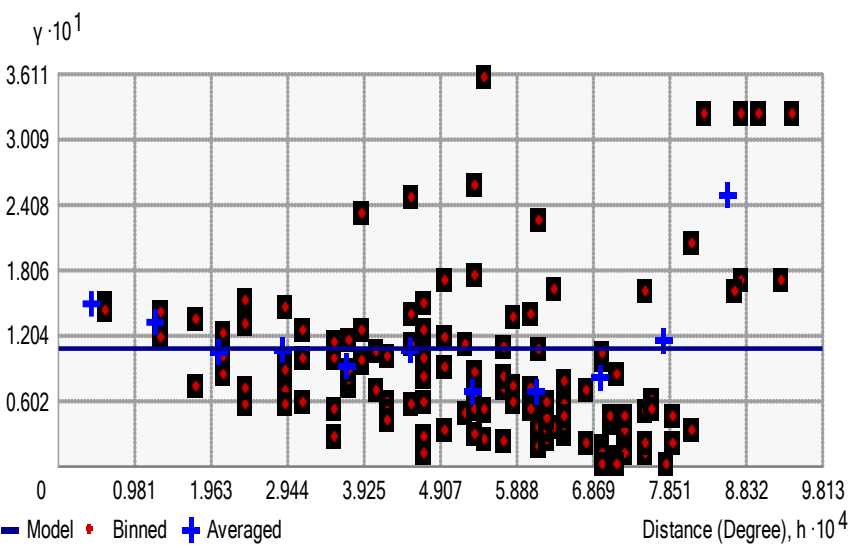

Fig. 8. Semivariogram curve of Water Content.

Nugget: 0.1087136 .

Major range: 0.0009813 .

Partial Sill: 0 .

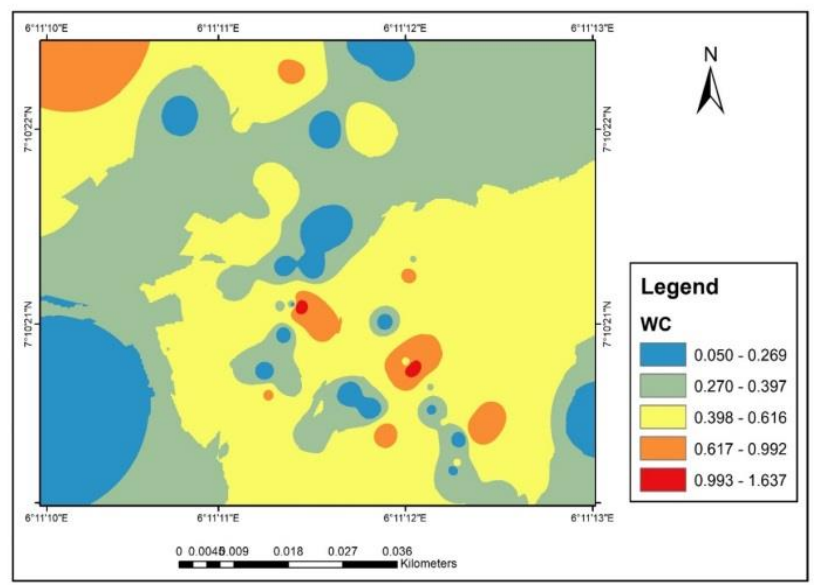

Fig. 9. Predicted Map Showing the Water Content Distribution of the study Area.

Fig. 8 shows the variogram of the water content. It has a nugget value of about 1.1 while the range of sample correlation is $9.8 \mathrm{~m}$. The distribution of water content shows no noticeable increment in values as most of the values falls around 0.398-0.616 (Fig. 9).

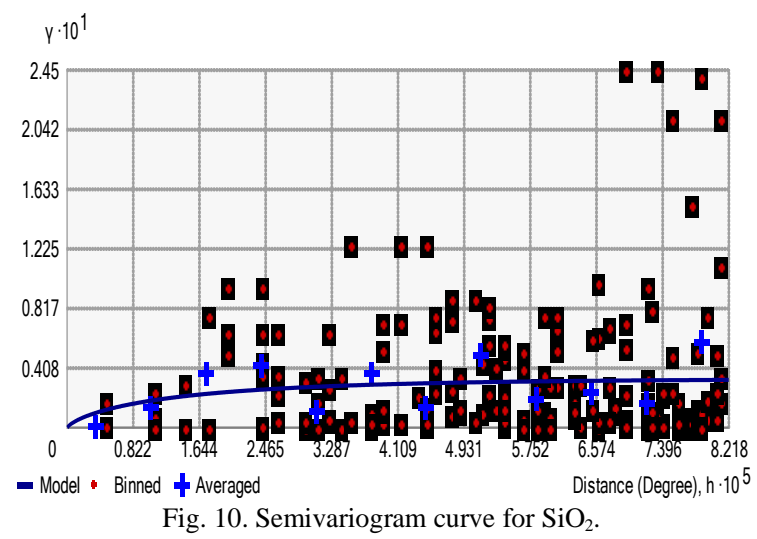

Nugget: 0 .

Major Range: 0.00006154989 .

Partial Sill: 0.03356681.

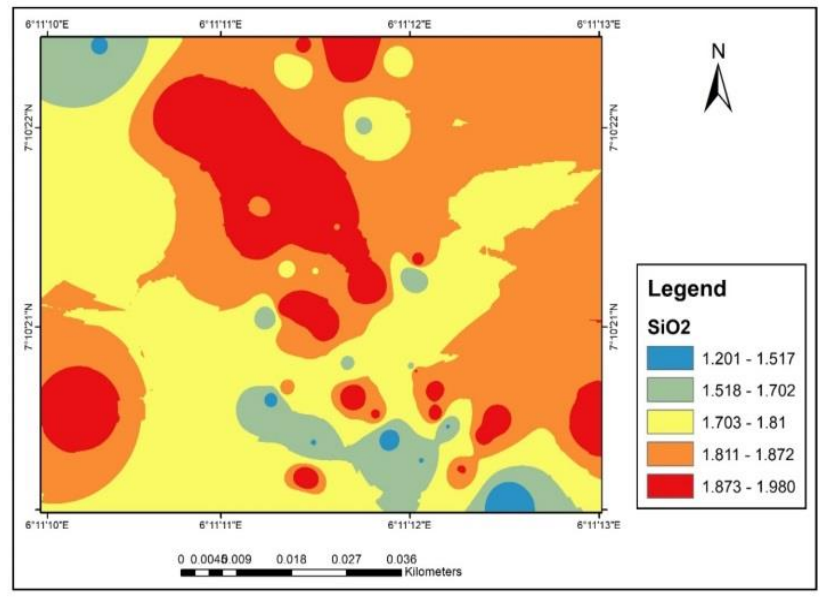

Fig. 11. Predicted Map showing the property $\left(\mathrm{SiO}_{2}\right)$ distribution of the studied area.

Fig. 10 shows the variogram structure of the $\mathrm{SiO}_{2}$ content. It produces a nugget effect of 0 , range of $6.5 \mathrm{~m}$ while the sill is 0.3. The distribution map (Fig. 11) has $\mathrm{SiO}_{2}$ ranging between $1.01 \%-1.98 \%$. The spatial distribution indicates that $\mathrm{SiO}_{2}$ increases from west to east.

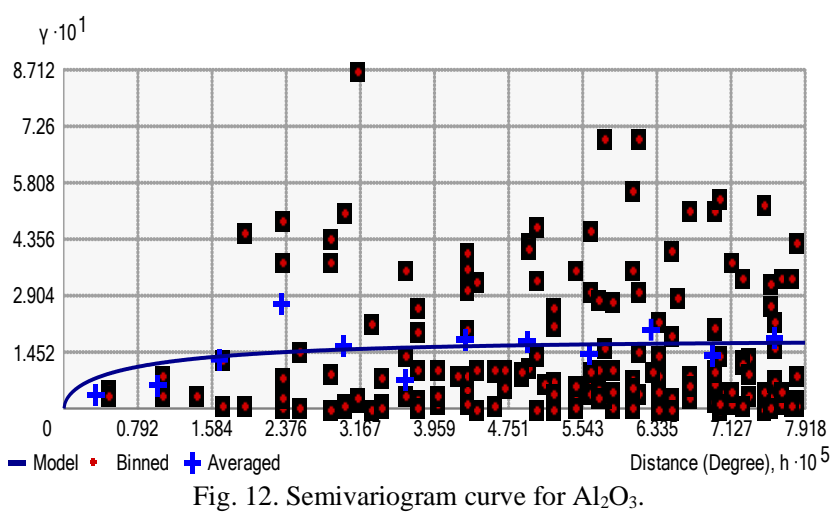

Nugget: 0 .

Major range: 0.00005868552 .

partial Sill: 0.1742742 .

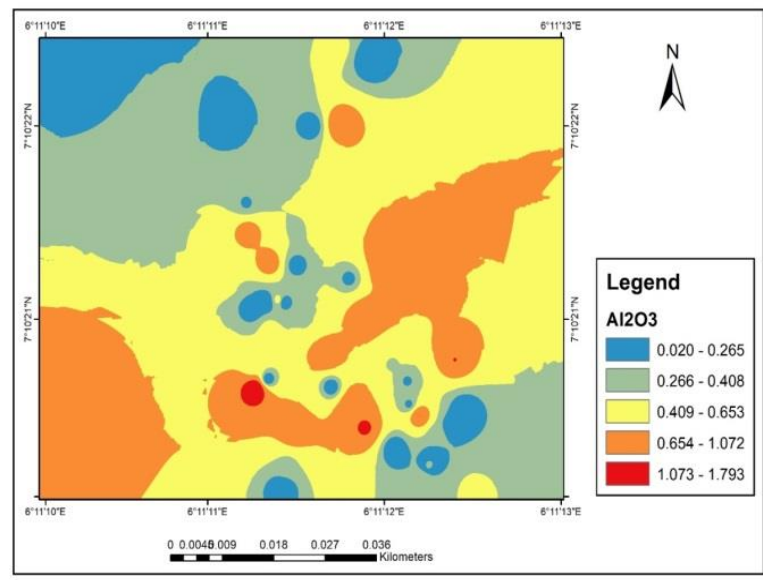

Fig. 13. Predicted Map showing the property $\left(\mathrm{Al}_{2} \mathrm{O}_{3}\right)$ distribution of the studied area.

The variogram curve of $\mathrm{Al}_{2} \mathrm{O}_{3}$ in Fig. 12, produces a nugget effect of 0 , range of $5.8 \mathrm{~m}$ while the sill is 1.7 . The distribution map (Fig. 13) indicates that $\mathrm{Al}_{2} \mathrm{O}_{3}$ ranges between 
$0.02 \%-1.78 \%$. The spatial distribution indicates that $\mathrm{Al}_{2} \mathrm{O}_{3}$ increases from around the central point of the deposit.

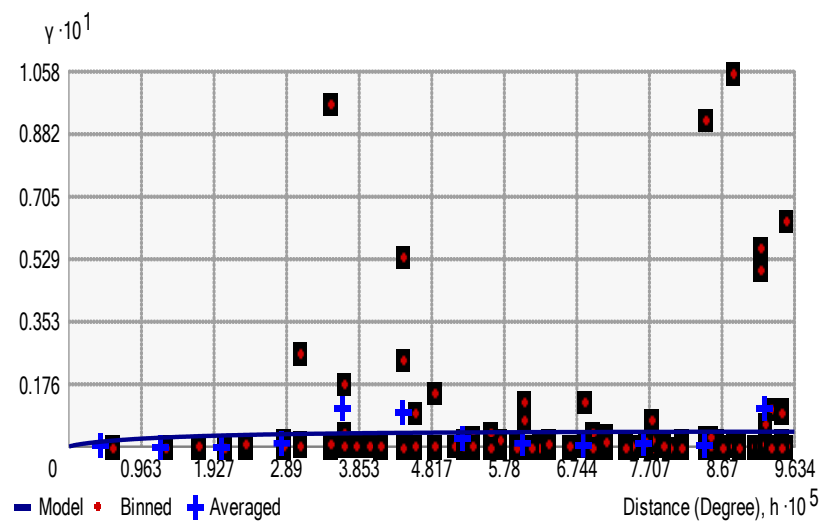

Fig. 14. Semivariogram curve for $\mathrm{Fe}_{2} \mathrm{O}_{3}$.

Nugget: 0.07794179 .

Major Range: 0.0002752181.

partial Sill: 0.06632192 .

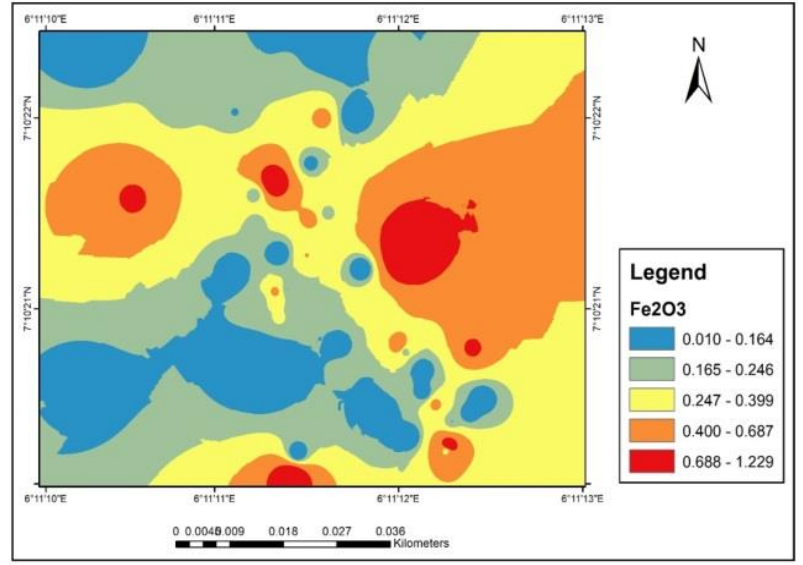

Fig. 15. Predicted Map showing the property ( $\mathrm{Fe} 2 \mathrm{O} 3)$ distribution of the studied area.

The variogram curve of $\mathrm{Fe}_{2} \mathrm{O}_{3}$ (Fig. 14) produces a nugget effect of 0.7 , range of $2.7 \mathrm{~m}$ while the sill is 0.6 . The distribution map (Fig. 15) indicates that $\mathrm{Fe}_{2} \mathrm{O}_{3}$ ranges between $1.01 \%-1.98 \%$. The spatial distribution indicates that $\mathrm{Fe}_{2} \mathrm{O}_{3}$ increases from west to east.

$\mathrm{r} \cdot 10^{1}$

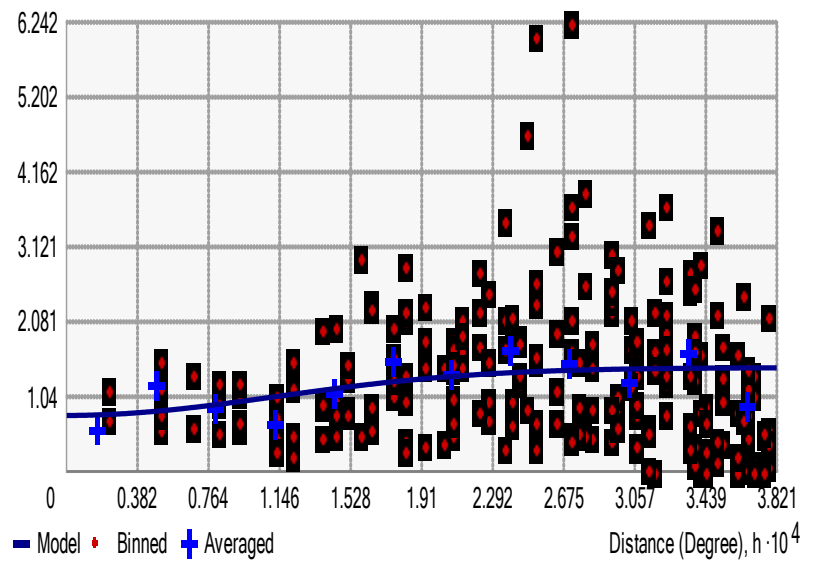

Fig. 16: Semivariogram curve for $\mathrm{MnO}$
Nugget: 0,

Major range: 0.00005868552

Partial Sill: 0.004289351

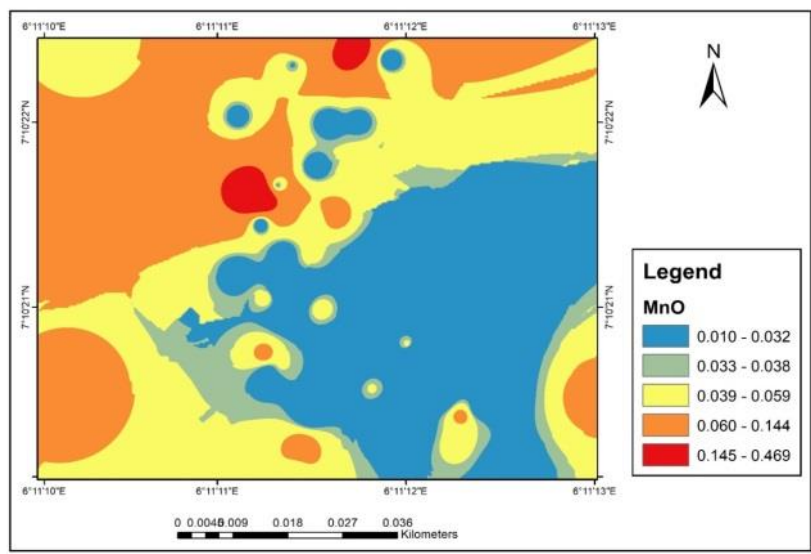

Fig. 17. Predicted Map showing the property $(\mathrm{MnO})$ distribution of the studied area.

The variogram plot of $\mathrm{MnO}$ in Fig. 16 produces a nugget effect of 0 , range of $5.8 \mathrm{~m}$ while the sill is 0.04 . The distribution map (Fig. 17) indicates that $\mathrm{MnO}$ ranges between $0.01 \%-0.47 \%$. The spatial distribution indicates that $\mathrm{MnO}$ show noticeable variation in values as most the values fall below $0.1 \%$.

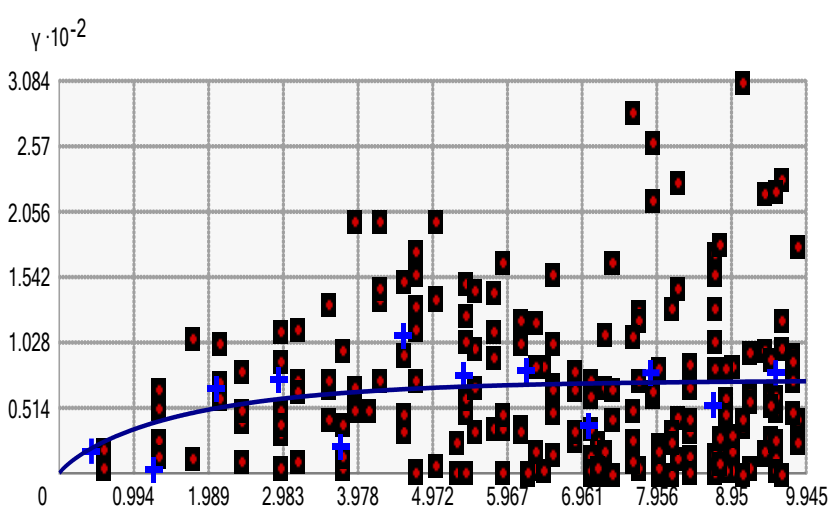

- Model * Binned + Averaged

Distance (Degree), $h \cdot 10^{5}$

Fig. 18. Semi variogram curve for $\mathrm{CaO}$.

Nugget: 0 .

Major Range: 0.00006154989.

Partial Sill: 0.007309623.

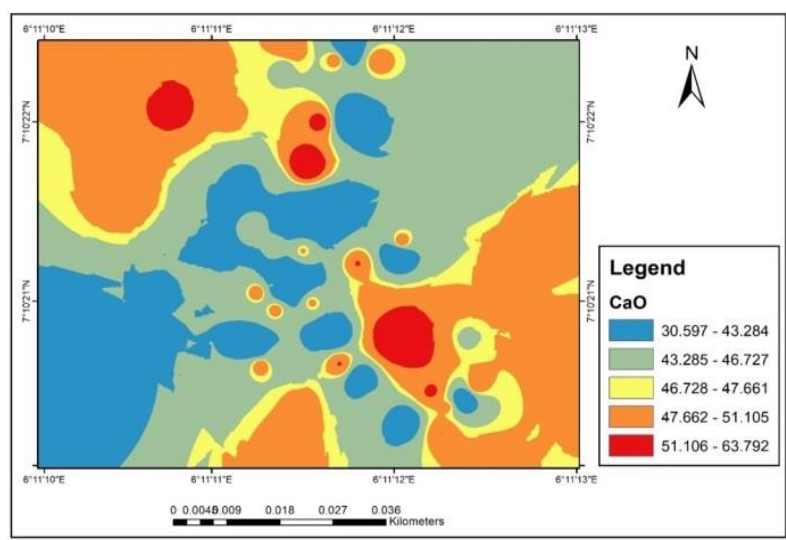

Fig. 19. Predicted Map showing the property $(\mathrm{CaO})$ distribution of the studied area. 
Fig. 18 presents the variogram curve of the $\mathrm{CaO}$ content in the deposit. From the curve, it could be observed that the nugget effect of 0 , range of $6.1 \mathrm{~m}$ while the sill is 0.7 . The distribution map indicates that $\mathrm{CaO}$ ranges between $30.6 \%$ $63.8 \%$ (Fig. 19).

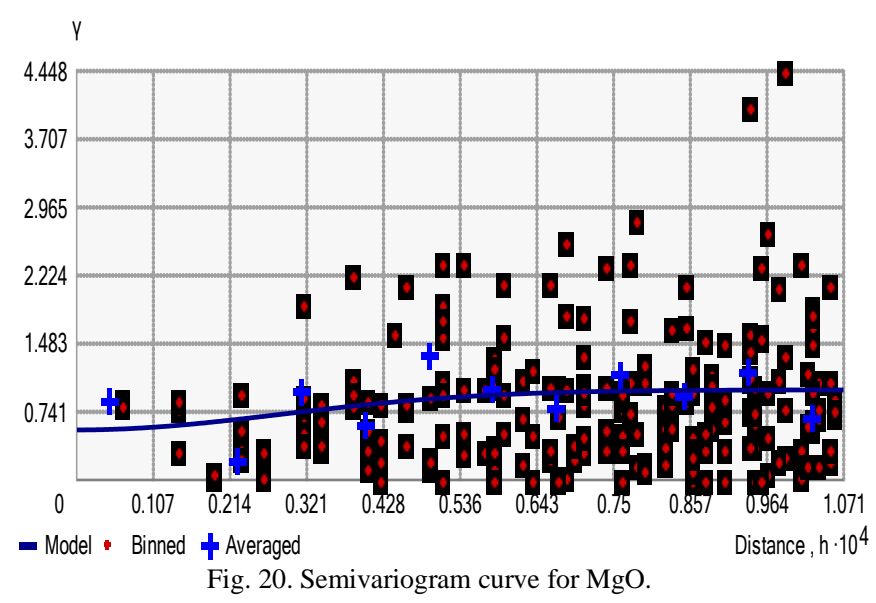

Nugget: 0.51043 .

Major Range: 0.00052345 .

Partial Sill: 0.8076456.

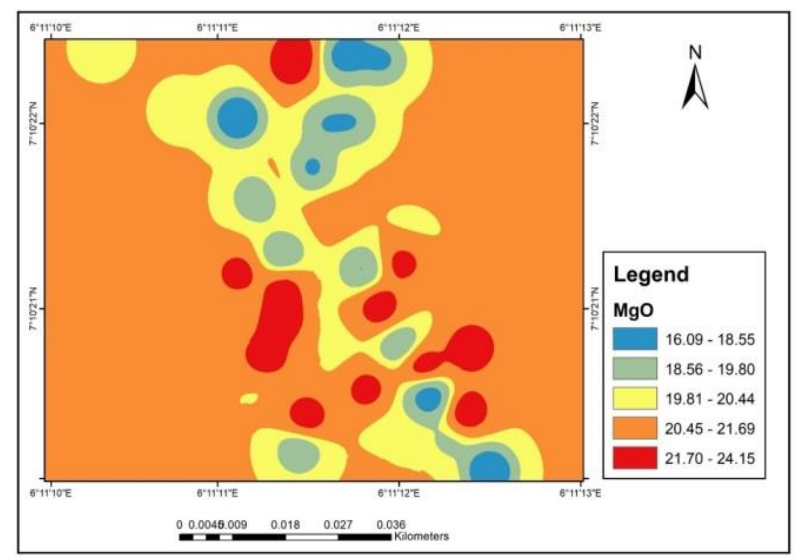

Fig. 21. Predicted Map showing the property $(\mathrm{MgO})$ distribution of the studied area.

The variogram map of $\mathrm{MgO}$ content (Fig. 20) produces a nugget effect of 0.6 , range of $5.2 \mathrm{~m}$ while the sill is 0.8 . The distribution map (Fig. 21) indicates that $\mathrm{MgO}$ ranges between $16.09 \%-24.15 \%$. The spatial distribution indicates that $\mathrm{MgO}$ has most of it values revolving around 20.45-21.09\% while few high values were observed in South-East direction.

\section{CONCLUSION}

This research focused on the geochemistry and application of semi-variogram tools to determine the mineral properties distribution of dolomite deposit in Ikpeshi. The following are the main conclusions:

1. In this study, the physical properties of Ikpeshi Golden Girl Quarry shows that the porosity ranges between $0.68 \%-3.24 \%$ with an average porosity of $2.13 \%$ and the water content gives an average value of $0.42 \%$.

2. The geochemical analysis carried out shows that $\mathrm{CaO}$ has an inverse relationship with the $\mathrm{SiO}_{2}$ and $\mathrm{MgO}$. This shows a high degree of purity of the dolomite. Thus, making it fit for engineering application.

3. Through the geostatistic tool (variogram) utilized, the grade distribution maps obtained from Ikpeshi Golden Girl Quarry shows variation in mode of distribution in all directions.

4. Information gathered at Ikpeshi Golden Girl Quarry site, shows that Golden Girl Quarry has a large deposit of dolomite, which is of economic importance for mining, construction and industrial purposes.

\section{ACKNOWLEDEMENT}

The authors wish to thank Laboratory staff of the Department of Mining Engineering, Federal University of Technology Akure, Nigeria and Department of Geology and Mining, Nasarawa State University Keffi, Nigeria We also sincerely appreciate the Prof. B.M. Olaleye and Engr D. J. Afu for their assistance.

\section{REFERENCES}

[1] W. A. Deer, R. A. Howie and J. Zussman, An Introduction to the Rock Forming Minerals, Longman, 1966, pp. 489-493.

[2] Klein, C and C. S. Hurlbut Jr Manual of Mineralogy, Wiley, 20th ed. 1998, p. 339-340.

[3] J.A. McKenzie, "The dolomite problem: An outstanding controversy" In Muller et al. (Ed.). Controversy in Modern Geology, (London Academic Press). 1991; 35-54.

[4] A.H. Brownlow, Geochemistry (2nd Ed.). Prentice Hall, New Jersey. 1996; pp. 580.

[5] Zenger D. H. and S. J. Mazzullo, Dolomitization. Hutchinson Ross.in Stroudsburg. Writte, 1992, pp. 410-420.

[6] M. A. Rahaman, "Review of Basement Geology of Southern Nigeria, In Kogbe", C. A. (Eds.), Geol. Nigeria Elizabethan press, Lagos, Nigeria, 1976, pp. 41-58.

[7] P. McCurry, "The Geology of the Precambrian to Lower Paleozoic Rocks of Northern Nigeria - A Review," Geology of Nigeria, Elizabethan Publ. Co., Lagos, 1976, pp. 15-40.

[8] D. G. Krige, "A Statistical Approach to Some Basic Mine Valuation Problems on the Witwatersrand," Journal of the Chemical, Metallurgical and Mining Society of South Africa, vol. 52, 6. pp. 119139. 1951

[9] T. A. Jones and Y. Z. Ma, "Geologic characteristics of hole-effect variograms calculated from lithology-indicator variables," Mathematical Geology, vol. 33, no. 5. pp. 615-629. Sept. 2001.

[10] I. B. Odeyemi, and S. M. Folami, "Geological andGeophysical Characteristics of Igarra Marble Deposit," Nigeria Journal of Mining and Geology, vol. 2, 199, pp. 63-797, 1976.

[11] America Standard Test Method (ASTM) Standard Test method, 1981. pp. $97-83$. 